\title{
Correlational study on self-compassion and college adjustment among university freshmen during distance learning
}

\author{
Indani Durrotul Aini ${ }^{*}$, Pratiwi Widyasari ${ }^{1}$ \\ ${ }^{1}$ Faculty of Psychology, Universitas Indonesia, Indonesia \\ *Corresponding author, e-mail: indani.durrotul@alumni.ui.ac.id
}

\begin{abstract}
When entering college, first-year students faced new challenges. College adjustment is necessary in the early period of college because it can predict college success. Covid-19 pandemic hinders college adjustment due to distance learning. Meanwhile, a previous study conceptually mentioned that selfcompassion supported college adjustment. This study examined the correlation between selfcompassion and college adjustment among first-year college students in distance learning during Covid-19 pandemic. Undergraduate students' batch $2020(\mathrm{~N}=381)$ were surveyed using SelfCompassion Scale and Student Adaptation to College Questionnaire. Pearson's correlation test showed a positive significant correlation between self-compassion and college adjustment. The strongest correlation was found between isolation and personal-emotional adjustment. These findings indicated that self-compassion tends to help a better college adjustment in a distance learning context.
\end{abstract}

Keywords: College adjustment; Distance learning; First-year college student; Pandemic Covid-19; Self-compassion

How to Cite: Aini, I. D. \& Pratiwi, W. 2021. Correlational study on self-compassion and college adjustment among university freshmen during distance learning. International Journal of Research in Counseling and Education, 5 (1): pp. 97-107, DOI: https://doi.org/10.24036/00459za0002

\section{Introduction}

When entering college, first-year students experience a life transition which describes a period of change in various aspects of life, ranging from personal responsibility, social support, and the campus environment (Astin \& Astin, 2015). First-year students must be more independent and have good self-regulation, moreover they are faced with adjustments to the new social and academic environment (Schulenberg \& Zarret, 2006). First-year students experience various challenges related to academic demands, autonomy towards needs and activities, and are more independent in learning than previous education levels (Credé \& Niehorster, 2011). Futhermore, first-year students have challenges recognizing the culture, values, and systems that apply to higher education as a new educational institution. From a social perspective, first-year students meet new friends, lecturers, and social groups related to specializations and campus organizations. Besides, the changing phenomenon is also felt from a personal-emotional perspective where psychological responses emerge, such as fear, stress, anxiety, and depression (Clinciu, 2013). These psychological responses harm the well-being of first-year students where students experience a decline in well-being during their first year in college (Gunnell et al., 2017).

Full of demands situations make students have to adapt to survive and be successful in carrying out higher education. Adjustment is a psychological process in adapting, overcoming, and managing everyday problems (Simons, Kalichman, \& Santrock, 1994). In the context of entering college, college adjustment is defined as multifaceted, involving demands of various types and degrees, and requiring various coping or adjustment responses that will vary in effectiveness (Baker, McNeil, \& Siryk, 1985). Multifaceted in college adjustment means that college adjustment consists of various dimensions that influence and determine the success of college adjustment. According to Baker and Siryk (1984), these dimensions consist of academic adjustment, social adjustment, personal-emotional adjustment, and institutional commitment/attachment. Furthermore, Baker and Siryk (1989) explain the definition of the four dimensions as follows, academic adjustment measures students' success in overcoming various academic demands that are characteristics of 
higher education. The social adjustment dimension measures students' success in overcoming interpersonalsocial demands related to their experience in college. Then, personal-emotional adjustment focuses on the intrapsychic state of students during the adjustment process to college and the degree to which students experience general psychological distress and concomitant somatic problems. Finally, institutional commitment/attachment measures the degree of student commitment to the goals of the educational institution and the degree of attachment to the particular institution that the student attends.

College adjustment is not an easy thing for first-year students to do. Difficulty in college adjustment is a common problem experienced by first-year students (Abdullah et al., 2014). Even college adjustment difficulties are the main problem for students who leave or drop out of college (Tinto, 1996). Difficulty in college adjustment is related to anxiety, anger, depression, and mental health (Clinciu, 2013). These depressive and anxiety symptoms can lead to suicidal thoughts and attempts (Skala et al., 2012). First-year students are also a vulnerable population to experience psychological or mental health problems related to decreased academic functioning (Bruffaerts et al., 2018). This fact is closely related to the limited experience of first-year students, so that college adjustment in terms of academic, social, physical-psychological, and institutional results is lower than that of second, third, and fourth-year students (Vijayalakshmi \& Sequeira, 2017).

The adjustment of the current first-year students is different from previous years because of Covid-19 pandemic. This pandemic has caused the implementation of education in all countries, including Indonesia, to be carried out remotely to avoid the spread of the virus in educational institutions (UNESCO, 2020). Indonesia, in this case, has implemented distance learning methods since March 17, 2020 (Kemendikbud, 2020). The Covid-19 pandemic increases anxiety and depression in Indonesian students (Hasanah et al., 2020). This phenomenon is also found in various countries globally, such as Bangladesh, China, and America (Islam et al., 2020; Chi et al., 2020; Wang et al., 2020). Research by Son et al. (2020) stated that increased stress and anxiety due to the Covid-19 pandemic impacted academic health and student lifestyles. The emergence of stress is caused by the demands of academic tasks, boredom at home and while doing online and distance learning, lack of social interaction, and poor network constraints (Livana, Mubin, \& Basthomi, 2020). Psychological or mental health problems that arise as a result of this change in learning methods can impact student performance and academic achievement (Son et al., 2020).

During the pandemic, college adjustment for first-year students is becoming increasingly difficult because all activities can only be done online. Implementing the Pengenalan Kehidupan Kampus Bagi Mahasiswa Baru (PKKMB) or Introduction to Campus Life for New Students in 2020 had to be carried out online (Direktorat Jenderal Pendidikan Tinggi, 2020). This condition makes first-year students have never met face-to-face with lecturers and new friends and have never directly oriented the campus environment. Consequently, it shows that first-year students have a different lecture experience from previous lectures' descriptions, resulting in a mismatch between expectations and reality regarding their experience as a student. The mismatch between expectations and experiences of first-year students can lead to feelings of being disconnected from the institution that can lead to academic failure and high drop-out rates among students (Pather \& Dorasamy, 2018).

Implementation of distance learning during the Covid-19 pandemic was an emergency in which most higher education institutions did not have attentive planning regarding changes to distance learning methods due to limited time availability (Fatoni et al., 2020). The limited availability of time makes adjustments to the use of technology types with the learning curriculum, competence of lecturers, and education staff less than optimal (Orlando \& Attard, 2015; Gillett-Swan, 2017). The diversity of financial backgrounds of students at universities in Indonesia can also affect the smoothness of distance learning because it relates to access to learning resources, technology-related skills, and financial constraints that can be a source of frustration for students (Hillstock \& Havice, 2014; Gillett-Swan, 2017; Jones \& Lau, 2010).

Previous research in the context of distance learning has also shown that first-year students' social and personal-emotional adjustments have low scores (Mittelmeier et al., 2019). This data can be explained because social interaction is limited, and students do not know their campus environment (Vonderwell, 2003; Woods, 2002). Interaction in distance learning is carried out through synchronous and asynchronous methods, each with a different approach (Watts, 2016). Interaction through these two methods can increase a sense of community (Luo, Zhang, \& Qi, 2017), where distance learning risks causing feelings of isolation due to a lack of sense of community (Song et al., 2004). Distance learning also has an increased risk of students dropping out compared to students who study face-to-face (The Australian, 2011).

College adjustment is an important factor in predicting the results obtained during college and future achievements (Clinciu \& Cazan, 2014). The transition to higher education with good academic, social, emotional, and college attachment is an important factor in determining student success in college (Credé \& Niehorster, 2011; Baker \& Siryk, 1999). This fact is also supported by Abdullah et al. (2014) that adjustment to 
lectures determines student academic achievement and self-development. Academic and social adjustment of students can explain differences in outcomes in higher education (Tinto, 1975). Adjustment to college is also positively related to good psychological well-being in first-year students (Zubir, 2012). In addition, Brown et al. (2015) said that adjustment during the first year was important to foster student engagement with distance learning methods to prevent students from dropping out.

In general, the factors that can affect the college adjustment of first-year students can be viewed from a personal and environmental perspective. First-year students' skills related to coping strategies are an important factor in the success of college adjustment (Katz \& Somers, 2017). The individual's ability to assess the conditions and demands that exist in the surrounding environment is an important thing that first-year students must have following the Transactional Model of Appraisal Coping by Lazarus and Folkman (1984). This model explains that the coping process or the individual's response to stressful situations depends on the demands in the environment, the resources that the individual has in dealing with these demands, and the appraisal process that depends on the two last things. Therefore, first-year students need to have adaptive coping strategy skills to help assess the sources of stress in the environment. Self-compassion can be an adaptive coping strategy for undergoing a college adjustment full of vulnerability to mental health (Dvořáková, Greenberg, \& Roeser, 2019).

Self-compassion is defined as compassion for the self by connecting oneself to events of failure, disability, or personal suffering (Neff, 2016). Self-compassion has three main components with pairs of opposing aspects in each component: self-kindness, as opposed to self-judgment; common humanity as opposed to isolation; and mindfulness, which is the opposite of over-identification (Neff, 2003a). When a first-year students have self-compassion, they treat himself well in the face of shortcomings by calming themselves down and talking positively to themselves (Neff, 2011). In addition, self-compassion also helps first-year students recognize the discomfort experienced as part of the human experience that cannot be avoided. Firstyear students who have self-compassion can also deal with painful thoughts of themselves without avoiding or exaggerating and managing their disappointments and frustrations by eliminating self-deprecation.

Neff (2003a) said that self-compassion could be an alternative coping because self-compassion provides an approach that is oriented towards active emotion regulation. In line with that, the research resulted by Dvořáková, Greenberg, and Roeser (2019) indicate that self-compassion can be a coping process and practice of self-regulation strategies in college transitions. Three causal processes can explain this; namely, selfcompassion can increase readiness to overcome problems (coping), produce an effective stress response through adaptive assessment of the source of stress, expand skilled coping resources, and then provide positive post-coping reflection. This mechanism is also supported by Gunnell et al. (2017), which say that self-compassion can be a protective factor for first-year students because self-compassion can increase the satisfaction of psychological needs, therefore relates to the well-being of first-year students.

Existing research on self-compassion in the context of education emphasizes that self-compassion is related to the well-being of students (Gunnell et al., 2017; Neely et al., 2009). Self-compassion in first-year college students was also found to increase life satisfaction (Hope et al., 2014), reduce homesickness and depression (Terry et al., 2013), and mediate the relationship between negative life events and depression (Chang et al., 2017). Research related to the relationship between self-compassion and college adjustment is still limited in number. Meanwhile, research conducted by Dvořáková, Greenberg, and Roeser (2019) found that the Mindfulness and Compassion (MC) model that explains the mechanism of self-compassion skills can be an alternative adaptive coping process in dealing with college students transition. However, this research is only preliminary research that uses literature studies and has not been proven through direct data collection. Another study conducted by Aydin (2016) on students in Turkey showed that self-compassion was associated with adjustment to college, whereas high self-compassion was associated with better adjustment in college life. However, in this study, the relationship between components and dimensions of college adjustment was not explained.

Based on the explanation from Dvořáková, Greenberg, and Roeser (2019) reviewed previously, this study was conducted to prove the relationship between self-compassion and college adjustment by collecting data directly from respondents, which previously studies have not done. This study also wants to see the relationship between self-compassion and college adjustment in a more specific context, namely distance learning during the Covid-19 pandemic and using the Indonesian student population. This paper is not only looking for the relationship between the two variables as a whole, but this study also looks at the relationship between each component of self-compassion and the dimensions of college adjustment. So that, the comparison of the strength in the relationship between each component of self-compassion and the dimensions of college adjustment could be defined. From the previous explanation, we assumed that there is a significant positive relationship between self-compassion and college adjustment in first-year students 
during distance learning. This research can enrich research related to college adjustment in the context of distance learning, where research on this phenomenon is still very limited in number.

\section{Method}

This research is a quantitative and correlational study of two variables (bivariate), with self-compassion as the first variable and college adjustment as the second variable. This study is also a cross-sectional study, where data collection is only done once.

Three hundred eighty-one participants can be included in the data processing process. Participants are undergraduate students (S1) University of Indonesia class 2020 who take full online learning or distance learning (PJJ) this semester. The range of age is $16-22$ years $(\mathrm{M}=18.15, \mathrm{SD}=0.632)$. The majority of participants consisted of 277 women (72.7\%) and were domiciled in Java (86.9\%). The participants are spread across three scientific clusters at the Universitas Indonesia, with almost half of them coming from the Social Humanities Cluster (48.6\%). Most participants have easy access to gadgets (41.5\%) but have poor internet signal quality $(65.6 \%)$.

The sampling technique used is non-probability sampling. More specifically, the sampling techniques used convenience and snowball sampling because researchers distributed questionnaires to first-year students at the Universitas Indonesia, which are more accessible to researchers. Researchers distributed questionnaires through parties who feel they have access to communication with first-year students at the Universitas Indonesia to distribute the questionnaire to participants who meet the criteria. This technique was chosen to facilitate researchers in obtaining research data easier (Gravetter \& Forzano, 2012).

The measuring instrument used to measure college adjustment is the adaptation of the Student Adaptation to College Questionnaire (SACQ) by Baker and Siryk (1999) $(\alpha=0.91-0.96)$ into the distance learning context by Mittelmeier et al. (2019) ( $\alpha=0.713-0.872$ ). The total items are 34 items consisting of 11 academic adjustment items (e.g., "Saya selalu mengikuti perkembangan tugas akademik saya"), 9 social adjustment items (e.g., "Saya puas dengan kehidupan sosial saya di Universitas Indonesia"), 6 personalemotional adjustment items (e.g., "Akhir-akhir ini, saya merasa tenang"), and 8 goal commitment/institutional attachment items (e.g., "Saya merasa bahwa saya cocok di Universitas Indonesia"). Participants answered using a 7-point Likert scale where a scale of 1 means that participants strongly disagree and 7 means that participants strongly agree with the statement in the item.

Self-compassion was measured using the Self-Compassion Scale (SCS) (Neff, 2003b) $(\alpha=0.93)$, which has been adapted into Bahasa Indonesia by Sugianto, Suwartono, and Sutanto $(2020)(\alpha=0.872)$. A total of 26 items consist of 5 self-kindness items (e.g., "Saya mencoba untuk mencintai diri saya ketika saya merasakan sakit secara emosional"), 5 self-judgment items (e.g., "Ketika saya melihat aspek-aspek diri saya yang tidak saya sukai, saya merasa sedih pada diri saya"), 4 common humanity items (e.g., "Ketika saya merasa sedih, saya mengingatkan diri saya bahwa ada banyak orang di dunia ini yang mengalami hal yang sama dengan saya"), 4 isolation items (e.g., "Ketika saya gagal pada hal yang penting bagi saya, saya cenderung merasa sendiri di tengah-tengah kegagalan tersebut"), 4 mindfulness items (e.g., "Ketika suatu hal menyakitkan terjadi, saya mencoba untuk melihat situasi secara berimbang"), and 4 over-identification items (e.g., "Ketika sesuatu yang menyakitkan terjadi, saya cenderung membesar-besarkan kejadian tersebut"). Participants respond questionnaire with a 5-point Likert scale where 1 indicated almost never and 5 indicated almost always.

For procedure, the researchers prepared all the items from the self-compassion and college adjustment measuring instrument in the research preparation stage. Next, the researchers conducted an ethical review. Researchers adapted the SACQ measuring instrument (Mittelmeier et al., 2019) to Bahasa Indonesia through a back-translation and expert judgment process. In addition, the researchers also conducted a reliability test and pilot study for testing the measuring instrument to the population of this study, namely first-year students at the University of Indonesia.

Based on the reliability test results, the response scale of the Student Adaptation to College Questionnaire (SACQ) was reduced from 9 points to 7 points because there were participants who had difficulty choosing the right scale to describe their condition. In addition, the researcher also decided to use the Typeform as a research questionnaire platform because the display was considered more attractive and user-friendly by the participants. Furthermore, the results of the trial of the SACQ measuring instrument showed that 4 items are less homogeneous in measuring the same construct (Crit $<0.2$ ), so that it needs to be revised (Nunnally \& Bernstein, 1994), which ranges from $-0.020-0.694$ (Crit ). After revising the items, there was an increase in the Crit value of the 4 revised items (Crit $=0.248-0.625$ ). After the measuring instrument was ready, the researcher tidied up and rechecked the online questionnaire to be distributed. Then, the researcher prepared links, posters, and introductory texts to be distributed to research participants. Researchers also prepared a 
reward in the form of electronic money totaling Rp. 400,000.00, which will be distributed to 20 selected participants.

At the data collection stage, the researcher contacted first-year students at the Universitas Indonesia whom the researcher knew in various faculties and/or other relations who had access to ask first-year students at the Universitas Indonesia to fill out the online questionnaire. When contacting the party who will distribute the questionnaire, the researcher also attaches an explanatory text regarding the purpose of data collection, participant requirements, estimated filling time, and rewards that participants can get along with a poster regarding the information to attract more attention so that they participate in the study. Researchers used social media as a platform to distribute questionnaires. The questionnaire consists of 3 main parts: demographic data, self-compassion measuring instrument, and college adjustment measuring instrument. The total duration of filling out the questionnaire is about 10-15 minutes.

Research data processing used descriptive and correlational analysis techniques using IBM SPSS software version 20. Descriptive statistical analysis was used to see the general description of participants' characteristics, college adjustment, and self-compassion. Furthermore, Pearson's correlation was used to see the significance of the relationship between self-compassion and college adjustment and the relationship between the self-compassion components and the dimensions of college adjustment.

\section{Results and Discussion}

Table 1 shows the college adjustment and self-compassion scores of 381 first-year students at the Universitas Indonesia. The college adjustment score had an average score of 4.76 (SD = 0.74). The range of college adjustment scores obtained ranged from 2.26 to 6.56. From the four dimensions of college adjustment, the personal-emotional adjustment has the lowest average score, which is 3.49 ( $S D=1.20)$. On the other hand, institutional attachment has the highest average score, 5.60 (SD = 1.04), and social adjustment of $5.57(\mathrm{SD}=0.82)$. On the self-compassion score, the mean score was $3.12(\mathrm{SD}=0.57)$. Based on Neff and Germer (2018), first-year students at the Universitas Indonesia can be categorized as having a moderate level of self-compassion. The range of college adjustment scores obtained ranged from 1.46 to 4.69. The common humanity component owns the highest average score, which is $3.60(\mathrm{SD}=0.77)$. Otherwise, the isolation had the lowest average score, which was $2.60(\mathrm{SD}=0.89)$.

Table 1. Variable Scores

\begin{tabular}{lcccc}
\hline \multicolumn{1}{c}{ Variable } & Mean $(\boldsymbol{M})$ & $\begin{array}{c}\text { Standard of } \\
\text { Deviation }(S D)\end{array}$ & $\begin{array}{c}\text { Maximum } \\
\text { Score }\end{array}$ & $\begin{array}{c}\text { Minimum } \\
\text { Score }\end{array}$ \\
\hline College Adjustment & $\mathbf{4 , 7 6}$ & $\mathbf{0 , 7 4}$ & $\mathbf{2 , 2 6}$ & $\mathbf{6 , 5 6}$ \\
$\quad$ Academic Adjustment & 4,17 & 0,85 & 1,73 & 7,00 \\
Social Adjustment & 5,57 & 0,82 & 3,22 & 7,00 \\
Personal-Emotional & 3,49 & 1,20 & 1,00 & 7,00 \\
Adjustment & & & & \\
Institutional & 5,60 & 1,04 & 1,75 & 7,00 \\
Attachment & & & 1,46 & 4,69 \\
Self-Compassion & 3,12 & 0,57 & 1,20 & 4,80 \\
Self-Kindness & 3,42 & 0,70 & 1,00 & 5,00 \\
Self-Judgment & 2,89 & 0,73 & 1,25 & 5,00 \\
Common Humanity & 3,60 & 0,77 & 1,00 & 5,00 \\
Isolation & 2,60 & 0,89 & 1,50 & 5,00 \\
Mindfulness & 3,40 & 0,69 & 1,00 & 5,00 \\
Over-Identification & 2,81 & 0,80 & & \\
\hline
\end{tabular}

The results of the analysis using Pearson's correlation coefficient showed a significant positive relationship between self-compassion $(M=3.12, S D=0.57)$ and college adjustment $(M=4.76, S D=0.74)$, $I(380)=0.55, p<0.001$, one-tailed. According to Dancey and Reidy (2007), the relationship between the two variables is moderate. With these results, the hypothesis in this study is accepted, namely that there is a significant positive relationship between self-compassion and college adjustment in first-year students in the context of distance learning during the Covid-19 pandemic. In other words, the higher the level of selfcompassion, the better the adjustment of first-year students during Covid-19 distance learning.

Table 2 shows that all components of self-compassion are significantly related to all dimensions of college adjustment. The relationship between isolation and personal-emotional adjustment has the strongest 
negative and significant relationship $(I(380)=-0.49, p<0.001)$ while the relationship between self-judgment and institutional attachment has the weakest negative and significant relationship $(I f 380)=-0.19, p<0.001)$.

Table 2. Correlation between Self-Compassion and College Adjustment

\begin{tabular}{|c|c|c|c|c|c|}
\hline \multirow{2}{*}{\multicolumn{2}{|c|}{ Variable }} & \multicolumn{4}{|c|}{ College Adjustment } \\
\hline & & Academic & Social & Personal- & Institutional \\
\hline \multirow{6}{*}{$\begin{array}{l}\text { Self- } \\
\text { Compassion }\end{array}$} & Self-Kindness & $0,30^{* *}$ & $0,39^{* *}$ & $0,35^{* *}$ & $0,25^{* *}$ \\
\hline & Self-Judgment & $-0,28^{* *}$ & $-0,24^{* *}$ & $-0,45^{* *}$ & $-0,19^{* *}$ \\
\hline & Common Humanity & $0,26^{* *}$ & $0,35^{* *}$ & $0,31^{* *}$ & $0,27^{* *}$ \\
\hline & Isolation & $-0,35^{* *}$ & $-0,29^{* *}$ & $-0,49^{* *}$ & $-0,27^{* *}$ \\
\hline & Mindfulness & $0,33^{* *}$ & $0,32^{* *}$ & $0,40^{* *}$ & $0,29 * *$ \\
\hline & Over-Identification & $-0,36^{* *}$ & $-0,35^{* *}$ & $-0,48^{* *}$ & $-0,28^{* *}$ \\
\hline
\end{tabular}

**. Significant correlation on $p<0,001$ (one-tailed)

The main study results indicate a significant positive relationship between self-compassion and college adjustment in the context of distance learning for first-year students. It can be interpreted that the higher level of self-compassion in first-year students, the better adjustment to college in the context of distance learning. The results of this study indicate that the Mindfulness and Compassion (MC) Model by Dvořáková, Greenberg, and Roeser (2019) and the results of Aydin's (2016) research on the relationship between selfcompassion and college adjustment are also found in the context of distance learning. Dvořáková, Greenberg, and Roeser (2019) explain that self-compassion can be a process to overcome the problems faced and become a self-regulation strategy in the process of adjusting to college. Three causal processes can explain this; namely, self-compassion can increase readiness to cope with problems (coping), generate a productive stress response through adaptive assessment of the source of stress, expand sources of skilled coping, later provide positive post-coping reflection.

Each component of self-compassion has an important role in promoting a healthy stress response by strengthening social-emotional, cognitive, and attentional competencies when dealing with college adjustment (Dvořáková, Greenberg, \& Roeser, 2019). The self-kindness component can provide and strengthen the socio-emotional competence of students experiencing many demands and adjustments in the academic, social, personal-emotional dimensions, and attachment to institutions, especially during distance learning. Being kind to oneself or self-kindness makes first-year students gentle, supportive, and self-aware as they make adjustments in college, especially during distance learning. On the other hand, judging their shortcomings or mistakes made during the adjustment process (self-judgment) prevents first-year students from adjusting because it weakens students' socio-emotional competence (Dvořáková, Greenberg, \& Roeser, 2019).

Having a cognitive assessment that other students also experience the demands and challenges faced during the transition to college helps first-year students to carry out the process more lightly and not make failure a fatal mistake (Dvořáková, Greenberg, \& Roeser, 2019 ). Adjustment challenges stemming from various aspects, namely academic, social, personal-emotional, and attachment to institutions. Moreover, distance learning methods during the Covid-19 pandemic often make students feel alone in dealing with various sources of stress and only themselves who are incompetent in face failure. Distance learning makes students feel less connected to teachers and other students (Woods, 2002). Through common humanity, firstyear students can respond to stressors with cognitive competencies where they can use a wider perspective when facing difficulties to be more accepting of their condition (Neff \& Pommier, 2013). Common humanity can also increase their sense of connection with the human experience more broadly (Neff, 2003a).

Mindfulness is a person's ability to recognize and balance painful thoughts and emotions (Neff, 2003a). In adjusting to college through distance learning, the demands that arise from the academic, social, personalemotional aspects, and relationships with institutions often make first-year students worry and think about things that may not necessarily happen in the future. This condition is inseparable from the limited experience of first-year students and the condition of the Covid-19 pandemic, which is not yet known when it will end. Hence, feelings and thoughts arise that the individual cannot face things that she or he also does not know for sure. Mindfulness can help first-year students to focus and be aware of the circumstances in their surroundings at that moment so that first-year students can fully experience the demands and challenges they face one by one with balanced thoughts and emotions (Dvořáková, Greenberg, \& Roeser, 2019). Excessive thoughts and emotions over the difficulties and demands of adjustment to college during 
distance learning that are being experienced or have not even occurred (over-identification) make first-year students less attentive to things happening during the adjustment process to college. Moreover, multitasking behavior in students increases during distance learning, making it difficult for students to focus when online learning takes place (Lepp et al., 2019).

This study also found that a significant positive relationship between self-compassion and college adjustment in the context of distance learning was also followed by a significant relationship between all components of self-compassion and all dimensions of college adjustment. The relationship between the components of self-compassion and the dimensions of college adjustment aligns with the main findings, namely that self-compassion and college adjustment is significantly positive. These results can also be interpreted that each component of self-compassion contributes to the relationship with the college adjustment dimension and vice versa.

The relationship between the personal-emotional adjustment dimension and the isolation component in distance learning has the strongest negative relationship among all the relationships between the selfcompassion component and the college adjustment dimension. These results can be interpreted that when first-year students experience difficulties adjusting to the personal-emotional adjustment during distance learning, the individual considers herself or himself to be the only one experiencing difficulties and feels alienated from his social environment. This result is supported by the finding that feelings of isolation or lack of sense of community are a challenge in distance learning (Song et al., 2004) even though synchronous and asynchronous methods seek to replace existing social interactions (Watts, 2016; Luo, Zhang, \& Qi, 2017). Therefore, personal-emotional adjustments during distance learning can be helped by using a broader perspective that all difficulties experienced by individuals are also experienced by other first-year students (common humanity). This conclusion is consistent with previous research, which showed that an increase in common humanity followed by a decrease in isolation was associated with emotion-focused coping selfefficacy in college students (Taylor et al., 2020).

Meanwhile, the relationship between self-judgment and institutional attachment in distance learning has the weakest negative relationship compared to the relationship between other components of selfcompassion on the college adjustment dimension. This result can be interpreted that the more first-year students give a rough assessment and judge their shortcomings, the more they are less well-adjusted in building relationships and closeness with the college they attend. The weak relationship between these two variables can be caused by the institutional attachment dimension, which includes demands that are not included in the other three dimensions of college adjustment (Baker \& Siryk, 1984). In addition, the context of the Covid-19 pandemic cannot see institutional attachments because student interactions with the campus environment and facilities are limited only online and remotely. This condition causes the relationship between institutional attachment and the components of self-compassion, including self-judgment, to be weak compared to other dimensions of college adjustment.

In order to improve and develop further research, some methodological suggestions can be taken into consideration. First, research can be conducted on a wider population of participants. For example, involving more diverse universities, so they have better external validity. Second, research can also be replicated in a variety of different situations. For example, they are staying in the context of distance learning but outside the context of the Covid-19 pandemic. This suggestion comes because the pandemic conditions provide many additional and unique factors to the relationship between self-compassion and college adjustments, such as increased anxiety, depression, and suicidal thoughts in students. Furthermore, further research can use regression analysis to determine the relationship between self-compassion and college adjustment and how much self-compassion affects college adjustment or vice versa.

The findings of this study can be used as the basis for interventions that the university can carry out to implement a program with a sharing agenda among first-year students regarding the difficulties faced during college adjustment during the Covid-19 pandemic. In the busy schedule of lectures, the university can schedule this sharing program as part of the lecture schedule in each faculty. This activity is done to increase the self-compassion of first-year students so that college adjustment can occur better. This program can be carried out during the Covid-19 pandemic in particular or during the transition period to enter lectures in general. In addition, the university can also conduct socialization about self-compassion skills in dealing with the demands encountered in the first year of college. The training can emphasize the importance of thinking that others are also facing difficulties (common humanity). This suggestion comes because many first-year students thought they were alone and less competent in facing the demands of higher education. This interpretation comes from the findings that isolation has the strongest relationship with the personalemotional adjustment of first-year students. Interventions related to personal-emotional adjustment need to be carried out because this adjustment dimension is closely related to first-year students' mental health, and the average score of this dimension has a strong relationship with each component of self-compassion. 


\section{Conclusion}

Based on the results of data analysis, there is a significant positive relationship between self-compassion and college adjustment in first-year students during distance learning in the context of the Covid-19 pandemic. This finding means that the higher the self-compassion level of first-year students, the better the first-year students will adjust to college during distance learning in the context of the Covid-19 pandemic. In addition, all components of self-compassion and all dimensions of college adjustment also show a significant relationship in first-year students. The findings of this study can be interpreted that first-year students who have good behavior towards themselves (self-kindness), feel that the difficulties experienced are part of the wider human experience (common humanity), and have a balance of mind and emotions (mindfulness) can help the college adjustment in terms of academic, social, personal-emotional aspects, and attachment to institutions.

\section{References}

Abdullah, M. C., Elias, H., Mahyuddin, R., \& Uli, J. (2014). Adjustment amongst first year students in Malaysian University. European Journal Of Social Sciences, 8(3), 496-505. http://merr.utm.my/id/eprint/4697

Astin, A. W., \& Astin, H. S. (2015). Achieving equity in higher education: The unfinished agenda. Journal of College and Character, 16(2), 65-74. https://doi.org/10.1080/2194587X.2015.1024799

Aydin, Y. (2016). Testing a model of psychological inflexibility, ruminative thinking, worry, and selfcompassion in relation to college adjustment [Doctoral dissertation]. http://etd.lib.metu.edu.tr/upload/12620101/index.pdf

Baker, R. W., McNeil, O. V., \& Siryk, B. (1985). Expectation and reality in freshman adjustment to college. Journal of Counseling Psychology, 32(1), 94-103. https://doi.org/10.1037/0022-0167.32.1.94

Baker, R. W., \& Siryk, B. (1984). Measuring adjustment to college. Journal of Counseling Psychology, $31(2), 179$. https://doi.org/10.1037/0022-0167.31.2.179

Baker, R. W., \& Siryk, B. (1989). Manual for student adaptation to college questionnaire. Western Psychological Services.

Baker, R. W., \& Siryk, B. (1999). SACQ: Student adaptation to college questionnaire: Manual. Western Psychological Services.

Brown, M., Hughes, H., Keppell, M., Hard, N., \& Smith, L. (2015). Stories from students in their first semester of distance learning. International Review of Research in Open and Distributed Learning, 16(4), 1-17. https://doi.org/10.19173/irrodl.v16i4.1647

Bruffaerts, R., Mortier, P., Kiekens, G., Auerbach, R. P., Cuijpers, P., Demyttenaere, K., Green, J. G., Nock, M. K., \& Kessler, R. C. (2018). Mental health problems in college freshmen: Prevalence and academic functioning. Journal of Affective Disorders, 225, 97-103. https://doi.org/10.1016/j.jad.2017.07.044

Chang, E. C., Yu, T., Najarian, A. S. M., Wright, K. M., Chen, W., Chang, O. D., Du, Y., \& Hirsch, J. K. (2017). Understanding the association between negative life events and suicidal risk in college students: Examining self-compassion as a potential mediator. Journal of Clinical Psychology, 73(6), 745-755. https://doi.org/10.1002/jclp.22374

Chi, X., Becker, B., Yu, Q., Willeit, P., Jiao, C., Huang, L., Hossain, M. M., Grabovac, I., Yeung, A., Lin, J., Veronese, N., Wang, J., Zhou, X., Doig, S. R., Liu, X., Carvalho, A. F., Yang, L., Xiao, T., Zou, L., ... Solmi, M. (2020). Prevalence and psychosocial correlates of mental health outcomes among Chinese college students during the coronavirus disease (COVID-19) pandemic. Frontiers in Psychiatry, 11. https://doi.org/10.3389/fpsyt.2020.00803

Clinciu, A. I. (2013). Adaptation and stress for the first year university students. Procedia-Social and Behavioral Sciences, 78, 718-722. https://doi.org/10.1016/j.sbspro.2013.04.382

Clinciu, A. I., \& Cazan, A. M. (2014). Academic adjustment questionnaire for the university students. ProcediaSocial and Behavioral Sciences, 127, 655-660. https://doi.org/10.1016/j.sbspro.2014.03.330

Credé, M., \& Niehorster, S. (2011). Adjustment to college as measured by the student adaptation to college questionnaire: A quantitative review of its structure and relationships with correlates and consequences. Educational Psychology Review, 24(1), 133-165. https://doi.org/10.1007/s10648-0119184-5

Dancey, C. P., \& Reidy, J. (2007). Statistics without maths for psychology. Pearson Education.

Direktorat Jenderal Pendidikan Tinggi. (2020). Surat nomor 631/E.E2/KM/2020 mengenai Panduan Umum Kehidupan Kampus Bagi Mahasiswa Baru (PKKMB) Tahun 2020. Kementerian Pendidikan dan Kebudayaan. https://dikti.kemdikbud.go.id/wp-content/uploads/2020/06/Surat-Pengantar-PanduanPKKMB-2020.pdf 
Dvořáková, K., Greenberg, M. T., \& Roeser, R. W. (2019). On the role of mindfulness and compassion skills in students' coping, well-being, and development across the transition to college: A conceptual analysis. Stress and Health, 35(2), 146-156. https://doi.org/10.1002/smi.2850

Fatoni, Arifianti, N., Nurkhayati, E., Nurdiawati, E., Fidziah, Pamungkas, G., Adha, S., Irawan, Purwanto, A., Julyanto, O., \& Azizi, E. (2020). University students online learning system during Covid-19 pandemic: Advantages, constraints, and solutions. Systematic Reviews in Pharmacy, 11(7), 570-576. http://www.sysrevpharm.org/fulltext/196-1602175161.pdf

Gillett-Swan, J. (2017). The challenges of online learning: Supporting and engaging the isolated learner. Journal of Learning Design, 101), 20-30. https://doi.org/10.5204/jld.v9i3.293

Gravetter, F. J., \& Forzano, L. B. (2012). Research methods for the behavioral sciences(4th ed.). Wadsworth.

Gunnell, K. E., Mosewich, A. D., McEwen, C. E., Eklund, R. C., \& Crocker, P. R. E. (2017). Don't be so hard on yourself! Changes in self-compassion during the first year of university are associated with changes in well-being. Personality and Individual Differences, 107, 43-48. https://doi.org/10.1016/j.paid.2016.11.032

Hasanah, U., Ludiana, L., Immawati, I., \& Livana, P. H. (2020). Psychological Description of Students in the Learning Process During Pandemic Covid-19. Jurnal Keperawatan Jiwa, 8(3), 299-306. https://doi.org/10.26714/jkj.8.3.2020.299-306

Hillstock, L. G., \& Havice, P. A. (2014). Exploring characteristics of retained first-year students enrolled in nonproximal distance learning programs. Journal of College Student Retention: Research, Theory \& Practice, 15(4), 575-603. https://doi.org/10.2190/CS.15.4.f

Hope, N., Koestner, R., \& Milyavskaya, M. (2014). The role of self-compassion in goal pursuit and well-being among university freshmen. Self and Identity, 13(5), 579-593. https://doi.org/10.1080/15298868.2014.889032

Islam, M. A., Barna, S. D., Raihan, H., Khan, M. N. A., \& Hossain, M. T. (2020). Depression and anxiety among university students during the Covid-19 pandemic in Bangladesh: A web-based cross-sectional survey. PLOS ONE, 15(8), e0238162. https://doi.org/10.1371/journal.pone.0238162

Jones, N., \& Lau, A. M. S. (2010). Blending learning: widening participation in higher education. Innovations in Education and Teaching International, 474), 405-416. https://doi.org/10.1080/14703297.2010.518424

Katz, S., \& Somers, C. L. (2017). Individual and environmental predictors of college adjustment: Prevention and intervention. Current Psychology, 36(1), 56-65. https://doi.org/10.1007/s12144-015-9384-0

Kementerian Pendidikan dan Kebudayaan Republik Indonesia. (2020, 17 Maret). SE Mendikbud: Pembelajaran secara daring Dan Bekerja Dari Rumah untuk Mencegah Penyebaran COVID-19. https://www.kemdikbud.go.id/main/blog/2020/03/se-mendikbud-pembelajaran-secara-daring-danbekerja-dari-rumah-untuk-mencegah-penyebaran-covid19

Lazarus, R. S., \& Folkman, S. (1984). Stress, appraisal, and coping. Springer Publishing Company.

Lepp, A., Barkley, J. E., Karpinski, A. C., \& Singh, S. (2019). College students' multitasking behavior in online versus face-to-face courses. SAGE Open, (1). https://doi.org/10.1177/2158244018824505

Livana, P. H., Mubin, M. F., \& Basthomi, Y. (2020). "Learning Task" attributable to students' stress during the pandemic Covid-19. Jurnal IImu Keperawatan Jiwa, 3(2), 203-208. http://dx.doi.org/10.32584/jikj.v3i2.590

Luo, N., Zhang, M., \& Qi, D. (2017). Effects of different interactions on students' sense of community in elearning environment. Computers \& Education, $115, \quad 153-160$. https://doi.org/10.1016/j.compedu.2017.08.006

Mittelmeier, J., Rogaten, J., Long, D., Dalu, M., Gunter, A., Prinsloo, P., \& Rienties, B. (2019). Understanding the early adjustment experiences of undergraduate distance education students in South Africa. The International Review of Research in Open and Distributed Learning, 20(3). https://doi.org/10.19173/irrodl.v20i4.4101

Neely, M. E., Schallert, D. L., Mohammed, S. S., Roberts, R. M., Chen, Y. (2009). Self-kindness when facing stress: The role of self-compassion, goal regulation, and support in college students' well-being. Motivation and Emotion, 33, 88-97. https://doi.org/10.1007/s11031-008-9119-8

Neff, K. D. (2003a). Self-compassion: An alternative conceptualization of a healthy attitude toward oneself. Self and Identity, 2, 85-102. https://doi.org/10.1080/15298860309032

Neff, K. D. (2003b). Development and validation of a scale to measure self-compassion. Self and Identity, 2, 223-250. https://doi.org/10.1080/15298860309027

Neff, K. D. (2011). Self-compassion, self-esteem, and well-being. Social and Personality Psychology Compass, 5(1), 1-12. https://doi.org/10.1111/j.1751-9004.2010.00330.x 
Neff, K. D. (2016). The self-compassion scale is a valid and theoretically coherent measure of self-compassion. Mindfulness, 71), 264-274. https://doi.org/10.1007/s12671-015-0479-3

Neff, K., \& Germer, C. (2018). The mindful self-compassion workbook: A proven way to accept yourself, build inner strength, and thrive. Guilford Publications.

Neff, K. D., \& Pommier, E. (2013). The relationship between self-compassion and other-focused concern among college undergraduates, community adults, and practicing meditators. Self and Identity, 12(2), 160-176. https://doi.org/10.1080/15298868.2011.649546

Orlando, J., \& Attard, C. (2015). Digital natives come of age: The reality of today's early career teachers using mobile devices to teach mathematics. Mathematics Education Research Journal, 28, 107-121. https://doi.org/10.1007/s13394-015-0159-6

Pather, S., \& Dorasamy, N. (2018). The mismatch between first-year students' expectations and experience alongside university access and success: A South African university case study. Journal of Student Affairs in Africa, 6(1), 49-64. https://doi.org/10.24085/jsaa.v6i1.3065

Schulenberg, J. E., \& Zarrett, N. R. (2006). Mental health during emerging adulthood: continuity and discontinuity in courses, causes, and functions. In J. J. Arnett \& J. L. Tanner (Eds.), Emerging adults in America: Coming of age in the 21st century (p. 135-172). American Psychological Association. https://doi.org/10.1037/11381-006

Simons, J. A., Kalichman, S. C., \& Santrock, J. W. (1994). Human adjustment. WCB/McGraw-Hill.

Skala, K., Kapusta, N. D., Schlaff, G., Unseld, M., Erfurth, A., Lesch, O. M., Walter, H., Akiskal, K. K., \& Akiskal, H. S. (2012). Suicidal ideation and temperament: An investigation among college students. Journal of Affective Disorders, 141(2-3), 399-405. https://doi.org/10.1016/j.jad.2012.03.010

Son, C., Hegde, S., Smith, A., Wang, X., \& Sasangohar, F. (2020). Effects of Covid-19 on college students' mental health in the United States: Interview survey study. Journal of Medical Internet Research, 22(9). https://doi.org/10.2196/21279

Song, L., Singleton, E. S., Hill, J. R., \& Koh, M. H. (2004). Improving online learning: Student perceptions of useful and challenging characteristics. The Internet and Higher Education, 71), 59-70. https://doi.org/10.1016/j.iheduc.2003.11.003

Sugianto, D., Suwartono, C., \& Sutanto, S. H. (2020). Reliabilitas dan Validitas Self-Compassion Scale Versi Bahasa Indonesia. Jurnal Psikologi Ulayat: Indonesian Journal of Indigenous Psychology. https://doi.org/10.24854/jpu02020-337

Taylor, S. B., Kennedy, L. A., Lee, C. E., \& Waller, E. K. (2020). Common humanity in the classroom: Increasing self-compassion and coping self-efficacy through a mindfulness-based intervention. Journal of American College Health, 1-8. https://doi.org/10.1080/07448481.2020.1728278

Terry, M. L., Leary, M. R., \& Mehta, S. (2013). Self-compassion as a buffer against homesickness, depression, and dissatisfaction in the transition to college. Self and Identity, 12(3), 278-290. https://doi.org/10.1080/15298868.2012.667913

The Australian. (2011, 21 September). Australian undergraduate attrition rates. http://www.theaustralian.com.au/higher-education/university-rankings/attritionrates/story-fna15id11226141560486

Tinto, V. (1996). Reconstructing the first year of college. Planning for Higher Education, 25(1), 1-6. https://eric.ed.gov/?id=EJ558395

Tinto, V. (1975). Dropout from higher education: A theoretical synthesis of recent research. Review of Educational Research, 45(1), 89-125. https://doi.org/10.3102/00346543045001089

UNESCO. (2020, 4 Maret). 290 million students out of school due to COVID-19: UNESCO releases first global numbers and mobilizes response. https://en.unesco.org/news/290-million-students-out-school-dueCovid-19-unesco-releases-first-global-numbers-and-mobilizes

Vijayalakshmi, N. \& Sequeira, A. H. (2017). Campus adaptations of engineering undergraduates across academic years. International Journal of Environmental and Science Education, 12(5), 1241-1267. http://www.ijese.net/makale/1896.html

Vonderwell, S. (2003). An examination of asynchronous communication experiences and perspectives of students in an online course: A case study. Internet and Higher Education, 6, 77-90. https://doi.org/10.1016/S1096-7516(02)00164-1

Wang, X., Hegde, S., Son, C., Keller, B., Smith, A., \& Sasangohar, F. (2020). Investigating mental health of US college students during the COVID-19 pandemic: Cross-sectional survey study. Journal of Medical Internet Research, 22(9), e22817. https://doi.org/10.2196/22817 
Watts, L. (2016). Synchronous and asynchronous communication in distance learning: A review of the

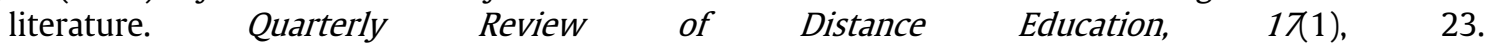
http://uindonesia.summon.serialssolutions.com

Woods, R. H. (2002). How much communication is enough in online courses? Exploring the relationship between frequency of instructor-initiated personal email and learners' perceptions of and participation in online learning. International Journal of Instructional Media, 29(4), 377-394. https://search.proquest.com/openview/b571e879a60b21a529af59493ab4f087/1?pqorigsite $=$ gscholar $\& \mathrm{cbl}=30932$

Zubir, D. M. (2012). Hubungan antara psychological well-being dan college adjustment pada mahasiswa tahun pertama Universitas Indonesia [Bachelor's thesis]. http://lib.ui.ac.id/detail?id=20357887\&lokasi=lokal\#parentHorizontalTab 